\title{
Health Needs Assessment and Determinants of Health-Seeking Behaviour among Elderly Nigerians: A House-Hold Survey
}

\author{
I. S. Abdulraheem
}

Department of Epidemiology and Community Health, College of Medicine, University of Ilorin, Ilorin, Nigeria Reprint requests to: Dr I.S. Abdulraheem, P. O. Box 5240, Central Post Office, Ilorin, Kwara State, Nigeria

E-mail: ibroraheem@yahoo.com

\begin{abstract}
Background: In the last decade the number of elderly citizens in Nigeria has increased and their health needs are becoming popularly recognized. A number of factors have also been recognized to determine health care seeking behaviour in these elderly.

Methods: The sample consisted of 756 households that had at least one resident who was aged 60 years and above (35\% of 2160 households). Multistage and proportionate sampling techniques were employed to select the study subjects. Structured interview were conducted to elicit information on health needs and determinants of health care seeking behaviour of household members aged 60 years and above.

Results: The most frequently reported illnesses were body pain (89.5\%), joint pain (86.4\%), generalized body weakness and fatigue $(81.5 \%)$, poor sight $(78.2 \%)$, fever $(71.3 \%) \%)$, irritability, anger, and nervous tension $(70 \%), \%)$, listlessness, depression, and headaches $(60 \%)$, and decreased mobility $(65.8 \%)$. More than two-thirds $(68.8 \%)$ of respondents had never visited health facilities in the last one year even for ordinary medical check-up. Family care/Family consultation was the first choice (44. 6\%) of treatment for the most frequently reported illnesses irrespective of age group and sex. Less than onethird $(28.7 \%)$ of the subjects were aware of their health needs. Receiving treatment when sick was the health needs mentioned by the majority $(89.4 \%)$ of the elderly. Poverty emerged as a major $(50.3 \%)$ determinant of health care seeking behaviour followed by nature of illness $(28.5 \%)$. The odds ratio that elderly from poor households will seek health care from unqualified health care practitioners was 0.7 $(95 \%$ confidence interval $(\mathrm{CI})=0.38-0.67)$; while the odds ratio that elderly from poor households will seek health care from qualified health care practitioners was 0.8 (95\% CI $=0.57-0.89)$. Self treatment had odds ratio of $1.7(95 \% \mathrm{CI}=0.38-0.67)$. After controlling the household's poverty status, there was still a significance difference $(\mathrm{P}<0.05)$ in age group and gender in terms of health care seeking behaviour.

Conclusion: Socio-economic indicators and nature of illness were the most pervasive determinants of health care seeking behaviour among the elderly, overriding age and sex, and in terms of health-care expenditure, the nature of illness and quality of service provided ranked the major determinants.
\end{abstract}

Keywords: Elderly, health needs, determinants, health care seeking behaviour

\section{Résumé}

Introduction: Dans la dernière décénnie le nombre des citoyens âgés au Nigéria avait augmenté et leur besoins sanitaires deviennent généralement réconnus. Un grand nombre des facteurs sont également reconnus afin de décider le comportement visant à la recherche des soins médicaux pour les âgés.

Méthodes: L'échantillon consiste en 756 membre de la maison qui avaient au moins en résident âgeé de 60 ans et plus (35\% de 160 foyers) Techniques d'échantillon multistage et proportionnel ont été utilisés afin de choisir les sujets d'étude. Entretien structure est fait afin de savoir des informations sur les besoins sanitaires et les déterminants des comportements visant à la recherche des soins médicaux des membre de la maison âgés de 60 ans et plus.

Résultats: Des maladies les plus fréquemment rapportées étaient douleur du corps $(89,5 \%)$ douleur de l'articulation $(86,4 \%)$, fatigue et faibless du corps en général $(81,5 \%)$, mauvaise vue $(78,2 \%)$, fièvre $(71,3 \%)$, irritabilité, colère, et la tension $(70 \%), \%)$, apathie, dépression, et maux de tête $(60 \%)$ et des diminutions dans la mobilité $(65,8 \%)$, plus de deux tiers $(68,8 \%)$ des sondés ne sont jamais allés aux centre hospitaliers au cours de la dernière année même pour un seul cas d'examen médical, soins familials/consultation familiale était le prémier choix $(44,6 \%)$ de traitement pour des maladies les plus fréquemment rapportées sans tenir compte du groupe d'âge et sexe. Moins d'un tier (28,7\%) des sujets 
étaient conscient de leur besoin sanitaire. Recevoir du traitement qu'on est malade était le besoin médical mentionée par la majorité $(89,4 \%)$ des âgés. La pauvreté est notée comme le déterminant principal du comportement visant à la recherche des soins médicaux suivi par la nature de la maladie $(28,5 \%)$. La proportion contraire que les âgés d'un foyer pauvre vont chercher des soins médicaux chez des médicins sans compétence était $0,7(95 \%)$ interval de confiance $(\mathrm{CI})=0,38-0,67)$; tandis que des proportions négatives que les âgés des foyers pauvres vont chercher des soins médicaux chez des médecins des soins médicaux qualifiés était 0,8 soit $95 \% \mathrm{CI}=0,57-0,89$ ) Traitement de soi-même a une proportion négative de 1,7 soit $95 \% \mathrm{CI}=0,38-067$ ) Après avoir controlé de niveau de la pauvrete du foyer, il y avait encore une différence remarquable $(\mathrm{p}<0,05)$ dans le groupe d'âge et genre en ce qui concerne le comportement en recherche des soins médicaux.

Conclusion: Des symptômes socio-économiques et nature de la maladie étaient les determinants envahissants du comportement visant à la recherche des soins médicaux parmi les âgés, au - dessus d'âge et sexe et du point du vue de la dépence sur des soins médicaux, la nature de la maladie et qualité du service fourni sont les déterminants majeurs.

Mots-clés: Besoin sanitaire, déterminants, comportement visant à la recherche des soins médicaux

\section{Introduction}

Nigeria is the most populous black nation and one of the poorest countries in the world. Despite the country's immense human and natural resources, little social progress has been made. Two-thirds of a population of more than 100 million live below the poverty line, and one-third survive on less than a dollar a day. ${ }^{1}$ The rise in number and proportion of older people has lead to concerns about societal and health consequences. Life expectancy in Nigeria was 36 years in 1960 , but is now 51 years for males and 53 years for females. 2,3 According to 1991 population census, $6 \%$ of the Nigerian population is aged $\geq 60$ years, the absolute number was more than 7.2 million. Approximately 200,000 people move into this age group every year considering annual growth rate of $2.8 \%$. It is projected that between 1980 and 2020 the population of the developing world is expected to increase by $95 \%$, whereas the elderly population will probably rise by almost $240 \% .{ }^{4}$ In view of this staggering statistics coupled with the annual growth rate of $2.8 \%$, population ageing will take place over a short period of time in Nigeria and the country will find it difficult to deal with its consequences.

Rural-to-urban migration, increase adaptation to western lifestyles like monogamy and non-communal dwelling are exacerbating loneliness and therefore put the elderly population in difficult situation. ${ }^{5}$ In addition, poverty and social exclusion contribute the greatest treats to their well being. ${ }^{6}$ Due to their marginal position in the society, the female elderly are especially disadvantaged. ${ }^{7}$ The health needs of older citizens needs to be addressed as their vulnerability is reflected in a higher ill-health burden and disability ${ }^{8}$ as well as gradual deterioration in perceived health outcome measurement scores with advancing age. ${ }^{9}$

\section{Materials and Methods}

\section{Study area}

The survey was conducted from June - August 2004 in six council wards in Ilorin Metropolis, Kwara State,
Nigeria. Ilorin Metropolis is a low-middle income community with poor industrial activities. The metropolis is characterized by heterogeneity in terms of ethnicity, culture and language but is predominantly occupied by Yoruba speaking people. Islam remains the most practiced religion followed by Christianity. A variety of health facilities (primary, secondary and tertiary) are available but lack appropriate facilities, medicines and personnel for geriatric care. These facilities are supported by a lot of private clinics and hospitals.

\section{Study design}

The survey was organized as a cross-sectional study. Six council wards (Ajikobi, Alanamu, Gambari, Fulani, Mogaji-Ngeri and Badari) were used.

\section{Sampling technique and data collection}

Six council wards were randomly selected and a census conducted for all households having at least one individual aged 60 years and above. The census result gave a total of 2160 households with at least one resident aged 60 years and above out of which 756 households with 1125 (sample size) elderly were used. A sampling frame of households was carried out in each council ward and a proportional sampling technique was used to determine the number of households and sample size from each council ward since population varies by wards. The sample size was computed using simple random technique. As a result of difficulty in ascertaining the age, important historical events were used to confirm the age of the participants.

Nine interviewers (community health workers and senior nurses who were experienced in survey methods) and three supervisors (post graduate students in public health with experience in field activities) were used for the survey. Both the interviewers and supervisors were trained on questionnaire contents and administration, eliciting information techniques as well as strategies in establishing good rapport and maintaining neutrality essential for obtaining complete and quality data. Modes of training included teaching/lecture, practical demonstration, case scenarios (role play) as well as 
question and answer sessions. The training spanned a period of 3 days. For easy and ready reference, training manuals were supplied to the interviewers and supervisors. The researcher including two research fellows served as resource persons. Informed consent was obtained prior to the conduct of the interviews. All survey activities were supervised and fine tuned by the researchers. The questionnaire was pre-tested in a separate council ward outside the study area to guarantee its contents validity. Efforts to improve the reliability and validity of the data included using culturally acceptable language, provision of intensive supervision, on-the-spot checks for inconsistencies and provision of necessary support. Besides general questions about sociodemographic status of the elderly, the questionnaire contained questions for assessing the living and standard conditions (food, hygiene), health needs and determinants utilization of health services. Health seeking behaviours were categorized as follows:

1. Consultation with qualified medical practitioners

2. Consultation with paramedics

3. Consultation with traditional health care practitioners

4. Consultation with over the counter drug sellers

5. Consultation with self and other family members

\section{Data analysis}

Data was analysed using SPSS version 10.0. ${ }^{10}$ Bivariate analyses were done to characterize group level differences in health service utilization between male and female. Independent variables were identified based on the results of bivariate analysis and their known influence on health service utilization. Logistic regression analysis was performed to identify determinants of health seeking/utilizing different types of health care. Chisquared and Student $t$ tests were used as tests of significance at the $5 \%$ level of significance. ${ }^{10,11}$

Availability of health services was assessed by the degree of satisfaction of the old people with the possibilities to reach a physician or a health worker, and finally, in case of a need, with the possibility to be admitted to a hospital.

\section{Results}

\section{Socio-demographic variables}

A total of 1125 elderly respondents took part in this survey, out of which 608 (54\%) were females and 517 $(46 \%)$ were males. The age of respondents shows slight difference with regards to sex (Table 1). Twothirds $(66.7 \%)$ of the females were widowed while approximately half $(49.6 \%)$ of the males were still married. Out of $745(66.2 \%)$ of respondents who were literate, there was a considerably higher number of males $(p<0.05)$, a large percentage $(42.8 \%)$ of them had higher education or university degrees as compared to elderly female respondents, who mainly had primary and secondary education. Three hundred $(26.7 \%)$ of the respondents were gainfully employed, usually in service or small-trade activities or they were self-employed. Those elderly that were not employed earned their living from money remitted by children $(46.2 \%)$, family members $(23.4 \%)$ or from pensions $(3.7 \%)$. Three-quarters $(74.6 \%)$ of respondents estimated their financial situation as bad and more than two thirds (69.5\%) assessed their present financial situation as worse than ten years previously. The respondents with higher or university education were observed to be relatively in better financial condition compared with those with the lowest level of education or illiterates and the difference was found to be statistically significant ( $\mathrm{p}$ $<0.05)$.

The greatest number of these respondents lived in extended and large families (60.7 \%); a lesser proportion $(28.6 \%)$ lived with their spouses while $10.7 \%$ live alone.

\section{Health condition (morbidity profiles)}

Table 2 shows the health condition of the respondents. The most frequently reported illnesses were body pain $(89.5 \%)$, joint pain $(86.4 \%)$, generalized body weakness and fatigue $(81.5 \%)$, poor sight $(78.2 \%)$, fever $(71.3 \%) \%)$, irritability, anger, and nervous tension $(70 \%)$, listlessness, depression, and headaches $(60 \%)$, and decreased mobility $(65.8 \%)$. The high percentages of morbidity pattern were due to multiple responses. The distribution of respondents by illnesses in previous 14 days by sex is shown in table 3. There were differences in morbidity profiles between age groups and sex. Notably women reported a much higher prevalence of illness than men and the difference was statistically significant $(\mathrm{p}<0.05)$.

\section{Health needs}

This study showed that in the last one year, medical, nursing and community health students, as part of their community-health service posting and duties, visited a small percentage $(9.6 \%)$ of elderly at home and primary health care center without prior request. Eleven percent of the elderly was visited by a nurse in order to receive therapy and $18.7 \%$ of old persons had opportunity to use services provided by physicians at their homes. There was no report of dentist visit of the elderly at home. An even lower proportion of old persons $(6.8 \%)$ had an opportunity in the last one year to consult their physicians by telephone. The average number of home visits to old people by physicians was less than $1(\mathrm{SD}=2.3)$ while the average number of home visits by nurses was 2 (SD = 30.1). Routine medical check-ups for early diagnosis of disease were found to be average (52\%). Most (87.4\%) of the respondents had no house-help at home for health assistance, and even a substantial percentage (72.4\%) had poor drug supply when sick.

\section{Healthcare seeking behavior}

Seven hundred seventy four $(68.8 \%)$ of respondents had never visited health facilities in the last one year even for ordinary medical check-up. The remaining $31.2 \%$ respondents who visited health facilities for one ailment or the other to see their doctors made 1 to 5 visits in the last one year with average of one visit 
per year. There was no significance difference in health service utilization between the age groups and sex. Family care/family consultation was the first choice $(44.6 \%)$ of treatment for the most frequently reported illnesses irrespective of age and sex (Table 4). Health worker $(22.9 \%)$ and patent drug seller $(18.4 \%)$ are the commonly consulted health care providers. The health worker includes trained nurses, community health extension worker and village health worker. Qualified medical doctor played little role in the health seeking behaviour. The odds that elderly from poor households will seek health care from unqualified health care practitioners was $0.7(95 \%$ confidence interval $[\mathrm{CI}]=0.38-0.67)$, while that for qualified health care practitioners was $0.8(95 \% \mathrm{CI}=$ 0.57-0.89).

Table 1: Age and sex of 1125 elderly respondents

\begin{tabular}{llll}
\hline $\begin{array}{l}\text { Age } \\
\text { (years) }\end{array}$ & Sex & \multicolumn{1}{l}{$\begin{array}{l}\text { Total } \\
(\%)\end{array}$} \\
\cline { 1 - 3 } & M & F & \\
\cline { 2 - 4 } 60-64 & No. (\%) & No. $(\%)$ & \\
$65-69$ & $130(25.1)$ & $154(25.3)$ & $284(25.2)$ \\
$70-74$ & $95(19.5)$ & $122(20.1)$ & $223(19.8)$ \\
$75-79$ & $73(14.1)$ & $110(18.1)$ & $205(18.2)$ \\
$80-84$ & $68(13.2)$ & $76(12.5)$ & $155(13.8)$ \\
$\geq 85$ & $50(9.7)$ & $64(10.5)$ & $114(10.2)$ \\
\hline Total & $517(100)$ & $608(100)$ & $1125(100)$ \\
\hline
\end{tabular}

Table 2: Distribution of elderly respondents who reported having been ill in the preceding 14 days

\begin{tabular}{llll}
\hline $\begin{array}{l}\text { Age } \\
\text { (years) }\end{array}$ & Sex & & $\mathrm{p}$ value \\
& $\mathrm{M}$ & $\mathrm{F}$ & \\
& No. $(\%)$ & No. $(\%)$ & \\
\cline { 2 - 3 } $60-64$ & $98(34.5)$ & $186(65.5)$ & $\mathrm{p}<0.05$ \\
$65-69$ & $76(34)$ & $145(66)$ & $\mathrm{p}<0.05$ \\
$70-74$ & $87(42.4)$ & $116(57.6)$ & $\mathrm{p}<0.05$ \\
$75-79$ & $60(38.7)$ & $95(61.3)$ & $\mathrm{p}<0.05$ \\
$80-84$ & $61(42.4)$ & $83(57.6)$ & $\mathrm{p}<0.05$ \\
$\geq 85$ & $47(41.2)$ & $65(58.8)$ & $\mathrm{p}<0.05$ \\
\hline
\end{tabular}

Table 3: Distribution of illness in preceding 14 days among elderly respondents

\begin{tabular}{llll}
\hline $\begin{array}{l}\text { Type of } \\
\text { illness }\end{array}$ & $\begin{array}{l}\mathrm{M}(\%) \\
\mathrm{n}=517\end{array}$ & $\begin{array}{l}\mathrm{F}(\%) \\
\mathrm{n}=608\end{array}$ & $\mathrm{p}$ value \\
\hline Body pain & $432(83.5)$ & $544(89.5)$ & $\mathrm{NS}$ \\
Joint pain & $487(94.2)$ & $576(94.9)$ & $\mathrm{NS}$ \\
Weakness & $324(62.9)$ & $489(80.4)$ & $\mathrm{p}<0.05$ \\
$\begin{array}{l}\text { and fatigue } \\
\text { Poor sight }\end{array}$ & $283(54.9)$ & $457(75.2)$ & $\mathrm{p}<0.05$ \\
Fever & $194(37.5)$ & $267(44)$ & $\mathrm{NS}$ \\
$\begin{array}{l}\text { Irritability } \\
\text { Depression }\end{array}$ & $172(33.3)$ & $305(50.2)$ & $\mathrm{p}<0.05$ \\
$\begin{array}{l}\text { Decreased } \\
\text { mobility }\end{array}$ & $443(85.7)$ & $289(47.5)$ & $\mathrm{p}<0.05$ \\
\hline NS: not significant & & & $\mathrm{NS}$ \\
\hline
\end{tabular}

Table 4: Types of health care utilised for reported illnesses among 1125 elderly respondents

\begin{tabular}{ll}
\hline Type of care utilised & No. $(\%)$ \\
\hline Self treatment & $524(46.6)$ \\
Health care worker & $258(22.9)$ \\
Qualified medical doctor & $54(4.8)$ \\
Patent drug seller & $207(18.4)$ \\
Traditional care & $82(7.3)$ \\
\hline
\end{tabular}

Table 5: Determinants of health care seeking behavior among 1125 elderly respondents

\begin{tabular}{ll}
\hline Determinants & No. (\%) \\
\hline Poverty & $566(50.3)$ \\
Nature of illness & $284(25.2)$ \\
Quality of service & $121(10.8)$ \\
Attitude of caregivers & $40(3.6)$ \\
Waiting time & $34(3.0)$ \\
Availability of service & $32(2.8)$ \\
Accessibility of service & $26(2.3)$ \\
Educational status & $22(2)$ \\
\hline
\end{tabular}

\section{Determinants of health seeking behavior}

A number of factors were reported in this study to influence healthcare seeking behaviour by the elderly (Table 5). The most common factor is poverty $(50.3 \%)$ followed by nature of illness $(25.2 \%)$, quality of service provided $(10.8 \%)$, attitude of health caregivers $(3.6 \%)$, waiting time $(3 \%)$, availability of service $(2.8 \%)$, accessibility in terms of distance $(2.3 \%)$ and level of education $(2 \%)$. Although a very small percentage $(3.8 \%)$ of respondents stated that these services were excellent, majority $43.5 \%$ were of the opinion that the availability of health services was satisfactory. Satisfaction of the respondents with the aforementioned health services did not show any difference in relation to sex, age, or education. The research showed that hospital treatment was used by $15.6 \%$ of respondents in the last one year, and of this, only $10.1 \%$ had a one week hospitalization. Both men and women of all age groups used hospital treatments equally during the last one year. Persons living alone in single households did not use hospital treatments more often.

Poverty status (self rated), age group, gender and education were used to predict the odds of respondents to seek healthcare from qualified medical practitioner, family (using home remedies), and patent drug seller (Table 6). Poverty and the level of education were found to be the most significant determinants of health seeking behaviour in the three models (qualified medical practitioner, family-using home remedies, and patent drug seller) used. Poverty reduced the odds of seeking health care from qualified medical practitioner but increased the odds of using home remedies from the family and consulting patent drug seller. Education increased the odds of seeking healthcare from qualified medical practitioner. 
Table 6: Odds ratio for utilising different types of health care and poverty, age, gender and education of 1125 elderly respondents

\begin{tabular}{|c|c|c|c|c|c|c|}
\hline Variables & Family care & & $\begin{array}{l}\text { Qualified } \\
\text { health care } \\
\text { practitioner }\end{array}$ & & $\begin{array}{l}\text { Patent } \\
\text { medicine } \\
\text { seller }\end{array}$ & \\
\hline & OR & $95 \% \mathrm{CI}$ & OR & $95 \% \mathrm{CI}$ & OR & $95 \% \mathrm{CI}$ \\
\hline $\begin{array}{l}\text { Poverty } \\
\text { (self- } \\
\text { related) }\end{array}$ & & & & & & \\
\hline Absent & 1.00 & & 1.00 & & 1.00 & \\
\hline $\begin{array}{l}\text { Present } \\
\text { Age (years) }\end{array}$ & 1.77 & $1.32-2.21$ & 0.46 & $0.38-0.67$ & $0.68^{\mathrm{s}}$ & $0 . .57-0.84$ \\
\hline$<75$ & 1.00 & & 1.00 & & 1.00 & \\
\hline $\begin{array}{l}\geq 75 \\
\text { Sex }\end{array}$ & 1.65 & $0.82-1.36$ & 1.01 & $0.69-1.54$ & $1.47^{\mathrm{s}}$ & $1.27-1.88$ \\
\hline Male & 1.00 & & 1.00 & & 1.00 & \\
\hline $\begin{array}{l}\text { Female } \\
\text { Education }\end{array}$ & 1.26 & $0.87-1.58$ & 0.83 & $0.61-1.21$ & 0.78 & $0.58-1.02$ \\
\hline $\begin{array}{l}\text { Yes } \\
\text { No }\end{array}$ & $\begin{array}{l}0.68 \\
1.00\end{array}$ & $0.51-0.93$ & $\begin{array}{l}0.59 \\
1.00\end{array}$ & $0.48-0.87$ & $\begin{array}{l}1.62^{\mathrm{s}} \\
1.00\end{array}$ & $1.26-2.02$ \\
\hline
\end{tabular}

\section{Discussion}

The purpose of this study was to assess the health needs and determinants of health seeking behaviour of the non-institutionalized population, 60 years and over, residing in Ilorin metropolis of Kwara State, Nigeria. The metropolis is polarized in culture, language and socio-economic activities, therefore the findings could be generalized about the rest of the country. Our results confirmed assessments of most surveys concerning polymorbidity of old age. More than $60 \%$ of the elderly rated their health condition as bad. Leading health problems include body pain, joint pain, generalized body weakness, fatigue and poor sight. The high prevalence of morbidity among the elderly found in this study is consistent with observations from other studies. ${ }^{8,}{ }^{12}$ A higher prevalence of illness among elderly females compared to elderly males, shows their vulnerability. Our study showed that women are more frequent users of health services than men as in another report. ${ }^{13}$ This similar to one report. ${ }^{13}$ The reasons for the difference in health care utilization could be the greater prevalence of illness among female, preference for women health care and availability of increased number of caregivers probably because women played more active role than men in the care giving process. Some research on sex differences in the use of health care services has focused on differences in the way men and women seek care and, to a lesser extent, on the degree to which the diagnostic and therapeutic steps taken by physicians may vary according to the sex of the patient. ${ }^{14}$

Health needs in terms of utilization of health care services showed poorly organized and inadequate home care, as part of primary health care service. This is an indication that care of the elderly has not been fully integrated into primary health care. This calls for concern and should be addressed by both policy makers and programme implementers. The World Health Organization has drawn the attention of its member states to the increasing number of elderly worldwide and the need to provide appropriate social and health care services to emerging elderly populations. $^{15}$

This study found that socio-economic status was the single most important determinant of healthseeking behaviour among the elderly. This is similar to findings from a previous study. ${ }^{16}$ Poverty status emerged as the major determinant of health seeking behaviour. As a result of this, most elderly relied on home remedies from the family since they could not afford orthodox health care service simply because of high cost. Poverty, an important determinant of health care seeking behaviour, has similarly been reported in a previous study. ${ }^{17}$

The preponderance of family care with home remedies (self treatment) as the most common treatment chosen by the elderly when sick is a reflection of poverty and lack of social security and health insurance for the Nigerian elderly citizens. It could also be due to traditional belief in the study area that illnesses among the elderly are better treated with home remedies. Although self-treatment is an alternative and supplement to formal health care, ${ }^{18}$ it is equally very important that health care decisions taken by sick individuals or their givers are both safe and appropriate, ${ }^{19}$ most especially self treatment in the case of the elderly people. ${ }^{20}$ Therefore, in order to make self-treatment safe and appropriate, some measures are needed to empower patients to make informed decisions. ${ }^{21}$ This study also revealed that apart from self-treatment, cheap care provided by the health care workers (paramedics) and drug store sellers are other important sources of seeking health care by the elderly. Geriatric knowledge and skills are not included in the syllabus (course contents) of paramedics or does drug store seller knows what 
medicine is contraindicated in old age. In view of this, these providers should be informed about health issues facing elderly people through formal and informal training. Basic training in use of essential drug list should be made available to all health care providers who are of greatest importance to the poor. Similarly managerial and regulatory measures should be introduced to control the use of potential drugs. ${ }^{22}$ Education of the elderly and their caregivers plays an important role as observed in this study, in reducing the use of potentially dangerous drugs by enhancing an individual's capacity to assess services offered, to judge a provider's competence and to evaluate whether costs are justified and reasonable. ${ }^{23}$ The impact of education found in this study reflects the association between health and education and therefore underscores the need to promote literacy so that capacity to act appropriately in health care environment is increased. ${ }^{24}$

Utilization of health care services by the elderly was low compared to their needs, especially with regards to home visits by physicians, nurses or social workers. Poverty is the most singe leading determinant of health seeking behaviour among the elderly. This could be reduced through offering of free health care services or subsidy for geriatric health care. Care of the elderly needs to be among priorities in annual health planning and policy formulation.

\section{References}

1. United Nations. Nigeria's economy at the crossroads. Africa Recovery 1999; 3:8

2. Baiyewu O, Bella AF, Adeyemi JD, Bamigboye EA, Jegede RO. Health problems and sociodemographic findings in elderly Nigerians. Afr J Med Sci 1997; 26: 13-17

3. Ogungbo BI, Gregson B, Mendelow D, Walker R. Cerebrovascular disease in Nigeria: what do we know and what do we need to know? Trop Doct 2003; 33:25-30

4. World Health Organization. Report of a WHO expert committee on health of the elderly. Demography and public health aspects of population ageing. WHO, Geneva, Technical Report Series 1989;779:14-17

5. Bongaats J, Zimmer Z. Living arrangements of older adults in the developing world: households' survey. J Gerontol 2002; 57 (suppl B): 5145-5157

6. Uncertainty rules our lives: the situation of older people in Bangladesh. Help Age International, Chiang Mai, 2000;19

7. Rahman O. The effect of spouses on the mortality of older people in rural Bangladesh. Health Transition Review 1997; 7:1-12

8. Kabir ZN, Tishelman C, Aguero Torres H, Chowdhury AMR, Winbland B, Hojer B. Gender and rural urban differences in reported health status by older people in Bangladesh.
Arch Gerontol Geriatr 2003; 37:77-91

9. Ahmed SM, Rana AKMN, Chowdhury M, Bhulya A. Measuring perceived health outcome in non western culture: does SF-36 have a place? Journal of Health Population and Nutrition 2002;20:334-342

10. Norusis MJ. SPSS/PC+4.0 for the IBM $\mathrm{PC} / \mathrm{XT} / \mathrm{AT}$ and PS2. Installation Guide and Manual. SPSS Inc., Chicago, 1990

11. Rimm A. Basic biostatistics in medicine and epidemiology. Appleton Century Crofts, Connecticut, 1980; 6-8

12. Ageing in Bangladesh: issues and challenges. Centre for policy Dialogue, Dakar, CPD 2000 (CPD Dialogue Report, No 23)

13. Health reports: How healthy are Canadians? 2001 annual report. Statistics Canada, Ottawa, 2001 Cat. No. 82-003-XPE

14. Mustard CA, Kaufert P, Kozyrskyj A, et al. Sex differences in the use of health care services. N Engl J Med 1998; 338:1678-1683

15. Hafez G, Bagchi K, Mahaini R. Caring for the elderly: a report on the status of care for the elderly in the eastern Mediterranean region. Eastern Mediterranean Health Journal, 2000; 6:636-643

16. Ahmed SM, Tomson G, Petzoid M, Kabir ZN. Socioeconomic status override age and gender in determining health-seeking behaviour in rural Bangladesh. Bull WHO 2005; 83:109-117

17. Cain MT. The activities of elderly in rural Bangladesh. Population Studies 1991; 45:189202

18. Steverson FA, Britten N, Barry CA, Bradley CP, Barber N. Self- treatment and its discussion in medical consultations: how is medical pluralism managed in practice? Soc Sci Med 2003; 57:513527

19. Abosed OA. Self medication: an important aspect of primary health care. Soc Sci Med 1984; 19: 699-703

20. Amoako EP, Richardson-Campell L, KennedyMalone I. Self medication with over the counter drugs among elderly adults. J Gerontol Nurs 2003; 29: 10-15

21. Thawani V, Gharpure K. Empowering patients. Regional Health Forum 1997; 2:51-54

22. Kamat VR, Nichter M. Pharmacies, self medication and pharmaceutical marketing in Bombay, India. Soc Sci Med 1998; 47:779-794

23. Bloom G, Standing $H$. Pluralism and marketisation in the health sector: meeting health needs in contexts of social change in low and middle income countries. Institute of Development Studies, Brighton, 2001(IDS Working Paper No 136)

24. Kickbusch IS. Health literacy: addressing the health and education divide. Health Promotion International 2001; 16:289-297 